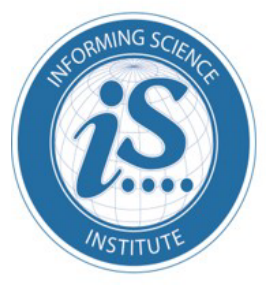

Interdisciplinary Journal of Information, Knowledge, and Management

An Official Publication

of the Informing Science Institute

InformingScience.org

IJIKM.org

Volume 15, 2020

\title{
CONSUMER ENGAGEMENT IN ONLINE BRAND COMMUNITIES: COMMUNITY VALUES, BRAND SYMBOLISM AND SOCIAL STRATEGIES
}

Haili Pan
Business School, Guilin University of Phlwy126@,126.com Technology, Guilin, P.R. China

\section{ABSTRACT}

Aim/Purpose

This study examines the kind of community value companies should provide when strengthening the relationship between customers and brands through the establishment of an online brand community, and how this kind of community value promotes customers' sense of community engagement and willingness to spread brand reputation. The paper also discusses how an enterprise's brand symbolism affects the relationship between community value and customers' engagement in online brand community. This study explored the important role of brand symbolism in the establishment of an online brand community.

Background

Many companies want to create online brand communities to strengthen their relationships with consumers as well as to provide better service and value to consumers, for example, Huawei's Huafen community (club.huawei.com), Apple's support community (support.apple.com/zh-cn), and Samsung's Galaxy community (samsungmembers.cn). However, these brand communities may have different interests and consumer engagement about the kind of community value to offer to their customers.

Methodology

This study uses data collection from questionnaire surveys to design a quantitative research method. An online questionnaire survey of mobile phone users in China was conducted to collect data on social value, cognitive value, brand symbolism, customer community engagement, and brand recommendation. The brands of mobile phone include Apple, Huawei, Samsung, OPPO, VIVO, MI, and Meizu. The researcher purchased a sample service of WJX, an online survey company (www.wjx.cn), and WJX company distributed the questionnaire to research participants. The WJX company randomly selected 240 subjects from their sample database and then sent the questionnaire link to research participants' mobile phones. Among the 240 research participants, the researcher excluded participants who lacked online brand community experience or had invalid data to qualify for data collection. After the researcher excluded partici-

Accepting Editor Felix O Quayson | Received: October 31, 2019| Revised: February 3, February 26, March 25, 2020 | Accepted: April 17, 2020.

Cite as: Pan, H. (2020). Consumer engagement in online brand communities: Community values, brand symbolism and social strategies. Interdisciplinary Journal of Information, Knowledge, and Management, 15, 65-90. https://doi.org/10.28945/4536

(CC BY-NC 4.0) This article is licensed to you under a Creative Commons Attribution-NonCommercial 4.0 International License. When you copy and redistribute this paper in full or in part, you need to provide proper attribution to it to ensure that others can later locate this work (and to ensure that others do not accuse you of plagiarism). You may (and we encourage you to) adapt, remix, transform, and build upon the material for any non-commercial purposes. This license does not permit you to use this material for commercial purposes. 
Contribution This study deepens the body of literature knowledge by combining online brand community value and brand symbolic value to explore issues that companies should consider when establishing an online brand community for their products and services. This study confirms that brands with high symbolic value establish communities and strengthen social values in the online brand community rather than reducing brand symbolism. Online brand community involves a horizontal interaction (peer interaction) among peers, which can have an effect on the symbolic value of brand (social distance).

Findings First, online brand community value (both cognitive and social value) has a positive impact on customer community engagement. Second, customer community engagement has a positive impact on customers' brand recommend intention. Third, the customer community engagement is a mediator between the online brand community value and the customer brand recommend intention. Most importantly, fourth, the symbolic value of the brand controls the relationship between community value and customer community engagement. For brands with high symbolic value, the community value should emphasize cognitive value rather than social value. For brands with a low symbolic value, the community provides cognitive or social value, which is not affected by the symbolism of the brand.

Recommendations Practitioners can share best practices with the corporate sectors. Brand owners for Practitioners can work with researchers to explore the characteristics of their online brand communities. On this basis, brand owners and researchers can jointly build and manage online brand communities.

Recommendation Researchers can explore different perspectives and factors of brand symbolism for Researchers that involve brand owners when establishing an online brand community to advance consumer engagement, community value, and brand symbolism.

Impact on Society Online brand community is relevant for brand owners to establish brand symbolism, community value, and customer engagement. Readers of this paper can gain an understanding that cognitive and social values are two important drivers of individual participation in online brand communities. The discussion of these two factors can give readers and brand owners the perception to gain more understanding on social and behavior activities in online brand communities.

Future Research Practitioners and researchers could follow-up in the future with a study to provide more understanding and updated research information from different perspectives of research samples and hypotheses on online brand community.

Keywords WOM, online brand community, brand symbolism, customer engagement

\section{INTRODUCTION}

Consumer word-of-mouth communication is an important corporate marketing strategy. In the era of social media, companies hope to strengthen their communication with customers by building brand communities that promote active participation and the sharing of valuable information. Muniz 
and O'Guinn (2001) define brand community as "a brand community is a specialized, non-

geographically bound community, based on a structured set of social relationships among admirers of a brand". Companies try to leverage the social and communicative nature of online brand communities to increase word-of-mouth communication. However, the spread of word-of-mouth marketing through the establishment of online brand community is needed. How then can a company's community marketing strategy increase customers' word-of-mouth communication intention? What kind of community value is effective in promoting customer participation? In addition, consumer interactions and sharing (such as information, usage method, and experience) are important issues for companies to consider. The author of this study argues that companies should enhance customer sense of engagement with the online brand community; a strong sense of engagement will increase their sharing and word-of-mouth communication behavior in the online brand community (Brodie et al., 2011; van Doorn et al., 2010).

Previous studies have pointed out that customer community engagement not only can bring loyal buyers to a company but can also turn customers into proponents, creators, and trial developers of new products, making them the company's "supernumerary" employees (Brodie et al., 2011; van Doorn et al., 2010; Verhoef et al., 2010). Such engaged customers generate stronger brand promises, brand trust, self-brand connection, emotional brand attachment, and loyalty. The implication is that engaged customers play an important role in word-of-mouth marketing such as providing references or recommendations to other customers for a product, service, or brand (van Doorn et al., 2010). For this reason, many companies have started to build brand communities to strengthen their brand relationships. Brand communities can provide users with both cognitive and social value (Dholakia et al., 2009; Nambisan \& Baron, 2009). Customer involvement in the online brand community is based on the needs of cognitive and social values provided by the online brand community (Dholakia et al., 2009). Brand community cognitive value is a direct, information-based value that supports the use of the product in question; community members seek advice before buying or information about potential problems, solutions, etc. (Dholakia et al., 2009). Brand community social value refers to the social and emotional value gained by customers through community participation and socializing relationships with other members (Muniz et al., 2001). The important questions to ask are, What type of online brand community value should a company provide? What kind of online brand community value is more conducive to customer community engagement? Is the impact of these online brand community values on word of mouth communication affected by the symbolic value of the brand?

Online community values influence the future of product support, helping others, and continuing community involvement, that is, they promote customer engagement (Brodie et al., 2011; Dholakia et al., 2004; S. Nambisan \& Baron, 2009; van Doorn et al., 2010). The symbolic value and experiential value embodied in the brand match the customer's own values and outlook on life (Kang \& Shin, 2016; Orth \& De Marchi, 2007). In addition to considering the brand as a commitment to product quality, customers often value the brand's symbolism (Orth \& De Marchi, 2007). In fact, in this era of high product homogeneity, the symbolism of the brand is even more prominent. The brand symbol includes both social symbolic and personal symbolic values. The social symbolic value reflects the customer's social identity needs. The personal symbolic value reflects the customer's self-realization, difference, and uniqueness needs (Keller, 1993). The brand symbol embodies social attributes, and the online brand community reflects social attributes. Can the matching of the brand symbol and online brand community promote customer community integration? Or, is there a contradiction between the personal symbolic value that represents the customer's diversity and uniqueness value and the online brand community interaction in which public interaction is the main form of communication? In other words, does brand symbolism affect the value needs of the customer community, which in turn affects the customer community engagement? What kind of community should the company develop in terms of the online brand community, customer community engagement, and brand symbolism? That is, what kind of community will play a role in the company under what circumstances and promote the customer's engagement with the community, thus also promoting the spread of word of mouth? 
In view of these professional curiosity questions from this study's researcher, based on combing customer community engagement, community values (social and cognitive values), brand symbolism, and word-of-mouth communication theory, this paper puts forward its research hypotheses. In summary, previous research has focused on the impact of community values on customer loyalty (Brodie et al., 2013; Casaló et al., 2008; Jang et al., 2008; Johnson \& Lowe, 2015; P. Nambisan \& Watt, 2011; Zhou, 2011). To the best of the researcher's knowledge in this study, the relationship between community values and customer community engagement and its impact on customer loyalty behaviors (such as brand recommend intention) have not been studied from the perspective of brand symbolic value.

\section{RESEARCH QUESTIONS}

Therefore, this study explores two research questions:

1) Can the social and cognitive value of the online brand community promote the customers community engagement and thus increase their willingness to word-of-mouth communication (brand recommend intention)?

2) Is the relationship between online brand community values and customer community engagement affected by the brand symbolic value?

This study's researcher constructed his own research model and research hypotheses as shown in Figure 1. The remainder of the paper is organized as follows: Literature review and hypotheses development section - a review of the constructs in the research model and deduct research hypotheses; Research methods section - with this study's research methods, by introducing sample sources and data collection methods and research model testing; Results section-the results of the hypothesis verification; Findings \& Discussion section—a summary and discussion of research questions; and Conclusion section — with the practical significance and limitations of this study.

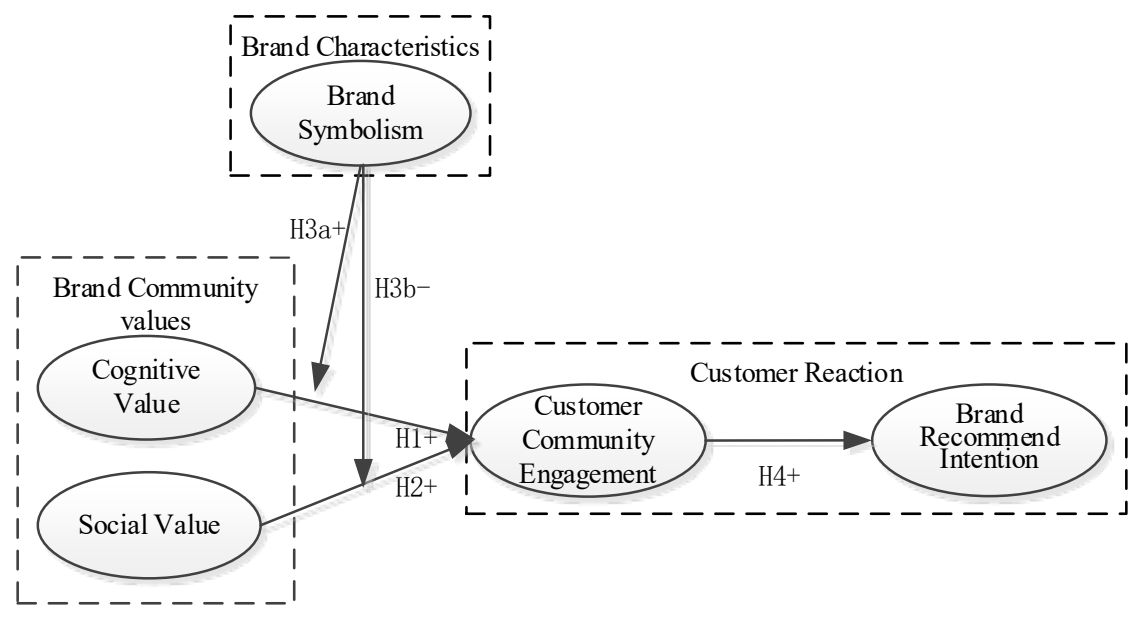

Figure 1. Research Model 


\section{LITERATURE REVIEW AND HYPOTHESES DEVELOPMENT}

\section{CUSTOMER COMMUNITY ENGAGEMENT}

\section{Definition and dimensions of customer community engagement}

Definition. Algesheimer et al.'s (2005) description of customer community engagement involves mainly customer attitudes (interests). Later, some scholars have suggested that the concept of customer community engagement should also include behavior (Brodie et al., 2013; Hollebeek et al., 2014; Kumar \& Pansari, 2016; van Doorn et al., 2010; Wirtz et al., 2013).Van Doorn et al. (2010) proposed that customer engagement includes attitudes such as trust, satisfaction, and commitment and is a behavioral expression of consumers' motivations about the company or brand. The customer behavior includes word-of-mouth communication referrals, helping others, publishing blogs, and writing reviews, very much in line with the online brand community (Wirtz et al., 2013). Kumar and Pansari (2016) define customer engagement as a customer's attitudes, behaviors, and levels of linkage among customers and between customers and businesses. The long-term, sustainable competitive advantage of a business is related to its ability to retain, maintain, and cultivate customers (Anderson et al., 2004; Gruca \& Rego, 2005; Rego et al., 2009). Maintaining and nurturing customers requires that companies not only pursue repeated purchases by customers, but also include retention of customers and cross-purchase, sales and transaction indicators, word-of-mouth communication, customer recommendations and suggestions, attribution, and online reviews (van Doorn et al., 2010). Brodie et al. (2013) believe that customer engagement includes three dimensions, cognition, emotion, and behavior, and emphasize cognitive absorption, emotional dedication, vigor, and interaction.

This study adopts the Baldus et al.'s (2015) definition: “Customer community engagement is of interest and the intrinsic motivation of customers' interaction with the online brand community." This study focuses on the level of linkage between the customer and the brand community, driven by the value of the online brand community. The higher the level of linkage (engagement degree) is, the stronger the intrinsic motivation will drive the customer to participate in community interaction and other word-of-mouth communication behaviors.

Dimensions. Researchers have identified three key dimensions to characterize customer engagement behaviors (Brodie et al., 2011; Hollebeek et al., 2014), which are cognitive processing, affection, and activation (Yang et al., 2019). The three-dimensional model (cognitive processing, affection, and activation) of customer engagement proposed by Brodie et al. (2013) is currently the most widely adopted by researchers (Obilo et al., 2020). Cognitive processing is defined as "a consumer's level of brand-related thought processing and elaboration in a particular consumer/brand interaction"; Affection refers to "a consumer's degree of positive brand-related affect in a particular consumer/brand interaction"; Activation is defined as "a consumer's level of energy, effort and time spent on a brand in a particular consumer/brand interaction" (Hollebeek et al., 2014, p.54).

\section{The formation process of customer community engagement}

The first step in the customer engagement process is based largely on the customer's demand for information. The process is highly interactive and experiential and includes a series of sub-processes such as learning, sharing, advocating, socializing, and co-developing (Wirtz et al., 2013). In online communities, customers are keen on non-tradable behaviors such as social interests, strengthening knowledge and reputation, and pursuing cost-saving economic benefits (Füller et al., 2010; S. Nambisan \& Baron, 2009). Enterprises can promote customer engagement by providing effective information exchange and interactive platforms (S. Baron \& Warnaby, 2011; Dholakia et al., 2009) and rewarding customers for their contribution (Füller et al., 2010; Kumar et al., 2010). Wirtz et al. (2013) determined that the factors driving customer community engagement include brand-based factors (brand identity, brand symbol value), social drivers (social value, social identity), and functional driv- 
ers (functional benefits, avoidance, uncertainty, quality of information, economy, and external incentives). Hennig-Thurau et al. (2004) point out that customers' willingness to contribute to an online brand community is mainly based on venting negative emotions, altruism (concern for others), selfenhancement, advice-seeking, social benefits, economic benefits, platform support, and helping those companies in which social benefits have the greatest impact on customers. From the perspective of cost-benefit analysis, Nolan et al. (2007) argue that an individual's engagement with an online brand community is based on a perceived value of cognition and interests that exceeds perceived risk levels. When customers perceive that interactive experience values and expectations outweigh the effort they are expending, the engagement will form quickly (Mollen \& Wilson, 2010). Moreover, the costbenefit balance they perceive may influence the strength of engagement (Nolan et al., 2007). That is, the higher a customer perceived value, the more the customer will promote the formation of engagement.

\section{Antecedents and consequences of customer community engagement.}

Antecedents. Researchers explore the factors driving customer community engagement from different perspectives (Le, 2018; Liu et al., 2019; Ray et al, 2014; Vohra \& Bhardwaj, 2019; Wirtz et al., 2013). These factors include social, cognitive, psychological, entertainment, and brand relationships, Wirtz et al. (2013) explore the drivers of online brand community engagement from brand, social, and functional factors. Vohra and Bhardwaj's (2019) study provides empirical evidence in terms of identifying both trust and commitment as antecedents to the construct of customer engagement, in the context of social media for emerging markets. Focusing on the entertainment, interaction, and trendiness dimension of luxury brand's social media marketing efforts can significantly increase customer engagement (Liu et al., 2019). Knowledge of self-efficacy, self-identity verification, and community identification positively influence online brand community engagements (Ray, 2014); Le (2018) suggested that posts contain informational and social contents, which have a positive impact on the online engagement of forum/Facebook users.

Consequences. Customer engagement is a key driver of the company's long-term success. The vast majority of marketers believe that engaged customers are very valuable and they are more likely to continue to trade with the company (Gopalakrishna et al., 2019). Customer engagement can improve corporate performance, including sales growth, competitive advantage, and profitability (Brodie et al., 2011). Engaged customers also play an important role in the development of new products/services and co-creative experiences and values (Ernst et al., 2017; Hoyer et al., 2010; S Nambisan \& Nambisan, 2008; Obilo et al., 2020; Rather, 2019). Engaged customers demonstrate confidence in the brand, brand integrity, brand pride, and passion for the brand (McEwen, 2001; McEwen \& Fleming, 2003). Van Doorn et al. (2010) argue that, for the customers, the engagement enhances their perceptions, attitudes, emotions, and social identities related to the product or brand. For the online service, consumers who have high level brand engagement lead to high level brand trust, brand commitment and brand loyalty (Khan et al., 2019). For an enterprise, it leads to gains economic benefit, reputation, competitive advantage, and product improvements. Customer community engagement promotes the integration of customer and corporate branding (Brodie et al., 2011; McAlexander et al., 2002), which in turn promotes commitment to the online brand community (Mathwick et al., 2008) and creates a new, loyal small group (Bagozzi \& Dholakia, 2006) that promotes purchases (Algesheimer \& Dholakia, 2006), enhances motivation for helping other members (Algesheimer et al., 2005), and generates useful information for the development of new products (S. Nambisan \& Baron, 2007). Among many outcome variables, loyalty, commitment, and empowerment dominate the research about online brand communities (Brodie et al., 2013).

\section{CUSTOMER COMMUNITY VALUE NEEDS}

Enterprises can obtain various values by establishing communities (Algesheimer \& Dholakia, 2006; Fuller et al., 2004; Jeppesen \& Molin, 2003; Verona, 2003). Of course, in turn, customers can also gain value through community participation. This value, expected or actual, is a key factor in custom- 
er community participation. S. Nambisan and Baron (2009) analyze the four value drivers of customer participation in an online brand community: cognitive value, social value, personal value, and entertainment value. The degree of these four values provided by the online brand community and perceived by the customer will influence the customer's actual community interaction behavior. S. Nambisan (2002) argued that the interaction of customers in the online brand community is essentially based on the interaction of three objects: products, community (society), and technology media. Product interaction is based on product knowledge; community interaction is customer-customer interaction in the online brand community; and technology media interaction is supported or constrained by computers and other media. Based on the theory of social exchange, Chang et al. (2015) studied the relationship between social support and customer citizenship in the online brand community, dividing the social support into information support and emotional support. Wang and Ma (2013) suggest that the key factors that drive customer interaction in the online brand community are their hedonic and practical needs. Customers' hedonic demands are mainly for community exchanges, pleasure, and relaxation; practicality is focused mainly on obtaining information and sharing knowledge.

This study proposes that information values refer to information support about products based on the online community interaction. Emotional support or hedonic demands are mainly about the social value of interpersonal communication centered on community interaction. Therefore, this paper analyzes mainly the value of customer interaction based on product interaction and community (social) interaction because the main reason for users to participate in an online brand community is to seek product-related knowledge. The other important factors that make up the online brand community are social interaction and identity display (Brodie et al., 2011; McAlexander et al., 2002). These two interactions correspond to the customer's cognitive and social value needs. However, technical media interaction (for example, website design is friendly, easy to use, and fully functional) is not so important because customers are very familiar with Internet technology and computer use knowledge, and the obstacles or restrictions imposed on customers are not so great. In addition, based on past research in the field of service marketing, Dholakia et al. (2009) suggest that the values that customers obtain in the online brand community are also divided into functional and social values. Based on this notion, this study refers to those authors' research to determine whether the value needs of customers participating in online brand community interactions are cognitive value needs and social value needs.

\section{COGNITIVE VALUE NEEDS}

Through an online brand community, companies provide customers with channels for interaction with others. The interaction not only benefits the company, but also promotes customer perception. Cognitive value is customers' perceived increase in their own knowledge of product use and is an important factor for customer involvement in the online brand community (Dholakia et al., 2009). Customers in the online brand community obtain useful knowledge through continuous interaction (McLure et al., 2000; Rothaermel, 2001) including product-related technologies and usage techniques. The author of this study believes that the reason that a customer first participates in an online brand community is usually for a specific purpose, which may be only known to the customer. Upon obtaining a satisfactory result, the customer's knowledge of the product is increased, and the reason for continued participation in the online brand community is to maintain identity as a community member. In other words, customers perceive the value of information during community interactions (Brodie et al., 2013). The cognitive process not only enhances knowledge about product use, but also increases customer-business transaction awareness and reduces transaction costs (Burnham et al., 2003; Chebat \& Kollias, 2000). Cognitive value is a direct, information-based value that supports the use of the product in question. Community members seek advice before buying, information about potential problems, solutions, etc. (Dholakia et al., 2009). In a firm-hosted online brand community, customer interactions are dedicated to solving other consumers' problems (Wiertz \& de Ruyter, 2007). With the development of cognitive value, customers gradually accumulate their own 
knowledge about products, making them more efficient in using products. Gray and Meister (2004) point out that when individuals' knowledge is rich, their cognitive framework will be correct, making them more efficient in the future when they manipulate and apply their own knowledge.

The cognitive value of customer perception has a positive influence on engagement behaviors such as product support activities in the online brand community in the future (S. Nambisan \& Baron, 2009). Nolan et al. (2007) point out that individuals' engagement with online brand communities is based on perceived perceptions and interests that exceed perceived risk levels. Wirtz et al. (2013) suggest that the factors driving customer engagement include functional benefits, avoidance of uncertainty, information quality, and other external incentive stimuli. These factors are based on the customer's knowledge of product-related information. Customers' acquisition of information enhances their knowledge of the product. According to the principle of reciprocity, customers who meet the needs of cognitive values will in turn have an increased desire to help others (Dholakia et al., 2004) and work more actively with others (Rosenbaum \& Massiah, 2007). In addition, as customers accumulate a wealth of product knowledge, they may demonstrate their product knowledge and problem solving skills through community interactions such as answering questions from others, suggesting product/service improvements, and developing new product development opinions and suggestions in order to gain self-efficacy through prestige or status and achievement (Harhoff et al., 2003; Jaakkola \& Alexander, 2014; McLure et al., 2000), and to promote a sense of community engagement. Consumers who search for more brand-related information show a higher preference for the specific brand (Loureiro et al., 2017). Therefore, this study proposes the following hypothesis:

H1: The cognitive value of the online brand community positively influences the customer community engagement.

\section{SOCIAL VALUE NEEDS}

In addition to providing product/service support, customer community interaction can also establish and maintain social relationships (Bagozzi \& Dholakia, 2006). The online brand community provides customers with social opportunities with others such as sharing personal experiences, providing suggestions and opinions, and generating new ideas. Customers engage in social relationships with other members through community involvement and gain broader social and emotional value (Muniz \& O'Guinn, 2001) that this study refers to as social value. Social value is the social relationship that customers establish over time with other customers in the online brand community (S. Nambisan, 2002). This relationship brings a variety of values to customers, including enhanced awareness of belonging and social identity (S. Nambisan, 2002). Previous studies on online brand communities have pointed out that social interaction is an important factor for community members joining an online brand community (Algesheimer et al., 2005) as well as a fundamental condition for the community becoming a social group (Muniz \& O'Guinn, 2001). Thus, the social identity and relationship bring meaningful social value to customers (Brodie et al., 2011; McAlexander et al., 2002). Community members categorize themselves as part of the online brand community and are borne with a natural need for belonging (Dholakia et al., 2009). Mutual understanding among members in the online brand community is necessary for quick access to information and advice. Quickly answering other people's questions in the online brand community, initiating new discussions, and providing suggestions about the online brand community are all ways for customers to establish social networks. This kind of social network brings positive social value to community members such as increasing job search opportunities, business opportunities, and greater access to prior innovative knowledge (Dholakia et al., 2009).

Like cognitive value, customer-perceived social value also has a positive impact on future engagement behaviors such as product support activities in the online brand community (S. Nambisan \& Baron, 2009). Customers who receive social support are more willing to collaborate with other customers (Rosenbaum \& Massiah, 2007). Social value leads to the behavior of helping others such as by providing information (Dholakia et al., 2009) and actively participating in community activities (Bro- 
die et al., 2011; Doorn et al., 2010). Hennig-Thurau et al. (2004) note that customers' willingness to contribute to an online brand community is based mainly on venting negative emotions, altruism (concern for others), self-enhancement, seeking advice, social benefits, economic benefits, platform support, and helping companies, where social benefits have the strongest influence on customers. Online information presented with high interactivity leads to more online engagement (Luarn et al., 2015). Of all types of posts, social posts have the most comment activity (Luarn et al., 2015). In addition, engagement is quickly formed when customer interactive experiences (social) values and expectations exceed the effort the customer puts in (Mollen \& Wilson, 2010). The common experiences make the community member feel a common identity, that is, community identification. Community identification has a positive impact on the online brand community engagement (Hsu et al., 2012).Community members often seek support through social dialogue (Dholakia et al., 2009), which promotes connections between members and enhances members' social value perception that in turn enhances their engagement with online brand communities (Wirtz et al., 2013). Gvili and Levy (2018) explore the eWOM (electronic word of mouth) from the perspective of social capital. For example, Jaakkola and Alexander (2014) indicate that customers' desire to establish relationships with companies and other customers promotes customer engagement. In addition, a social factor like reputation (i.e., labels or badges) helps to increase consumer's engagement (Hanson et al., 2019).Therefore, this study proposes the following hypothesis:

$\mathrm{H} 2$ : The social value of the online brand community positively influences the customer community engagement.

\section{BRAND SYMBOLISM}

Symbolic value concerns people's need to maintain their identity, strengthen their self-image, or express themselves (J. L. Aaker, 1997). More often than not, a brand's symbolic value reflects a product's external characteristics and usually involves non-product related attributes. Rather, it involves the customer's potential social recognition, personal expression, and self-esteem needs (Orth \& De Marchi, 2007). Customers achieve external utility such as congregation, uniqueness, and prestige through brand consumption. Brand symbolic value plays an important role in the formation of customer brand preferences because it provides the customer with the brand's self-expression and symbolic value, thus facilitating the customer's impression management (J. L. Aaker, 1999; Lautman, 1991). Homburg et al. (2015) suggest that symbolic value in the form of a brand's functional value, symbolic value, and aesthetic value has the strongest influence on customers' purchase intentions and word-of-mouth communication.

According to Vigneron and Johnson (2004), brand symbolic value can be divided into two types: interpersonal influence and self-influence. At the type of interpersonal influence, the symbolic value of consumer perception can be attributed to prestige value and social self-expression value; at the type of self-influence, the symbolic value of consumer perception can be attributed to intrinsic self-value, unique value, and hedonic value. Bauer and Hammerschmidt (2005) also suggest that brand symbolism has both external and internal value with external value reflecting the brand user's social status and group membership. Brand value can also help the customer to create a unique personal image and express the unique personality needs value. This view is basically similar to that of Vigneron and Johnson (2004) that highlights the external social status of symbolic value and the individual's intrinsic personality and unique value needs. When people promote their tastes through specific patterns of consumption, they are promoting a symbolic boundary to confirm differences from the collective. Therefore, there is an important social status demarcation between the social core and the periphery (Mathwick et al., 2008). From this perspective, the brand symbol has both a value of "seeking commonality" with group ownership, and a "different" value that promotes uniqueness.

Customers generally think that high symbolic brands (such as high-grade goods and luxury goods) provide better product and service quality and higher grades (J. L. Aaker, 1999). These brands are symbols of social prestige and prominent status. Customers use high symbolic brands to demonstrate 
superiority of social identity and to distinguish themselves from others (D. A. Aaker, 1996). If more people use the high symbolic brand, the customer will perceive the brand as a popular product and no longer a symbolic, but a social attribute brand. As their perception of superiority and uniqueness is threatened, customers become less likely to advertise brands that make them unique, thus avoiding others' becoming consistent with themselves (Tian et al., 2001). The assumption of this study's researcher leading to hypothesis three is that in order to maintain their uniqueness, customers are generally reluctant to engage in word-of-mouth activities. Therefore, in the online brand community, customers may not need more social interaction if they perceive the symbolic value of the brand to be relatively high. Too much social interaction may cause customers to feel that many people are using the brand, and thus there are many similarities with others, and their reason for participation in the online brand community is more likely to be obtaining relevant information about the product. Therefore, this study proposes the following hypothesis:

H3: Brand symbolic value (a) positively moderates the relationship between cognitive value needs and customer community engagement and (b) negatively moderates the relationship between social value needs and customer community engagement.

\section{CUSTOMER COMMUNITY ENGAGEMENT AND BRAND RECOMMENDATION}

The researcher of this study explored the impact of customer community engagement on brand recommendation intention in two ways. First, the researcher examined the direct effect of customer community engagement on brand recommendation intention. Second, the researcher considered customer community engagement as a mediator between community value (cognitive value and social value) and brand recommendation intention.

\section{The direct effect of customer community engagement on brand recommendation}

Godes and Mayzlin (2009) reported that the effectiveness of traditional media advertising is declining (especially for younger groups). Corporate managers are paying more attention to the role of wordof-mouth communication among consumers in promoting brand building and sales (Kozinets et al., 2010). In brand communities, the cost of word-of-mouth communication referrals is very low and can be quickly disseminated both inside and outside of communities. Moreover, word-of-mouth recommendations have a positive effect (Brodie et al., 2013). Consumers gather in an online brand community because of their common interests. They share and exchange experiences about the brand. Consumers also put more trust in brand information provided by their peers as a basis for decision-making (Wasko \& Faraj, 2005). Customer community engagement has a positive impact on consumers' continued use intention, word of mouth recommendation intention, and community activity participation intention (Algesheimer \& Dholakia, 2006; Algesheimer et al., 2005; Bagozzi \& Dholakia, 2006; Brodie et al., 2013; Mathwicket al., 2008; S. Nambisan \& Baron, 2007). In an online brand community, consumers gain both the cognitive value of a product or brand and the social value of community interaction (Brodie et al., 2011; McAlexander et al., 2002). Engaged consumers have a positive effect on awareness and reputation of the brand and may disseminate information about the company or brand (Doorn et al., 2010). Consumers perceive support from the online brand community. The higher the consumer is engaged with the online brand community, the more the consumer is willing to spread information by word of mouth (Le, 2018). Therefore, this study proposes the following hypothesis:

H4: Customer community engagement has a positive influence on brand word-of-mouth communication referral intention.

\section{The mediating role of customer community engagement}

Baldus et al. (2015) define customer community engagement as "the intrinsic motive of customers' interaction with online brand community." This internal driving force inspires consumers to interact with other members of an online brand community. Satisfaction of consumers' needs of cognitive 
value and social value promotes their integration into brand communities. Regarding cognitive value, according to the principle of reciprocity, consumers who have gained cognitive value from an online brand community will in turn desire to help others (Dholakia et al., 2004). In addition, as consumers have more knowledge of the brand or product, they may also help others (self-efficacy effects) (Harhoff et al., 2003; McLure et al., 2000). For example, the use of word-of-mouth communications such as replies and micro-blogs to promote brand or product information encourages or suggests to other people to buy the same brand. Regarding social value, community members gain social support through community interaction. As the interaction deepens, the relationship between community members is strengthened, such that members of the community have a stronger perception of the social value of the online brand community and often seek support through social dialogue (Dholakia et al., 2009). This dialogue promotes the connection among members and enhances their social value perception, thereby promoting the association of community members with the online brand community (Wirtz et al., 2013). Jaakkola and Alexander (2014) note that customers' desire to build social relationships with companies and with other customers will promote customer engagement, and the sense of online brand community formed by the customer's social value satisfaction in the online brand community is conducive to customer behavior of blog publishing word-of-mouth communication referrals related to their experiences with the company. Therefore, this study proposes the following hypothesis:

H5: Customer community engagement plays (a) a mediating role in the influence of cognitive value on brand recommendations and provides (b) a social value on brand recommendations.

\section{RESEARCH METHODS}

This study examines relationships between online brand community, brand, and customer. The community dimension includes the cognitive value and social value provided by the online brand community. The brand dimension considers primarily the symbolism of the brand. The customer dimension examines the perceive response of the customer to the online brand community. Taking the dimensions together, the paper extracts the relationship between community value, customer community engagement, and brand symbolism. This study uses data collection from questionnaire surveys to design a quantitative research method.

\section{SAMPLE}

This study used online survey questionnaires to collect data from mobile phone users in China. Some basic information of these mobile phone users is shown in Table 1. The reason for choosing this group of consumers is that mobile phones have become very important in people's lives and work, and not just because of their communication value. As a result, people's discussions about mobile phones are also increasingly frequent. Many mobile phone companies have strengthened their interaction with customers through establishing an online brand community. Therefore, the mobile phone online brand community appears suitable as a venue for user community experience.

An online questionnaire survey of mobile phone users was conducted to collect data on social value, cognitive value, brand symbolism, customer community engagement, and brand recommendation. All measurement items are showed in the Appendix. The brands of mobile phone include Apple, Huawei, Samsung, OPPO, VIVO, MI, and Meizu. The researcher purchased a sample service of WJX, an online survey company (www.wjx.cn), and WJX company distributed the questionnaire to research participants. The WJX company randomly selected 240 subjects from their sample database and then sent the questionnaire link to research participants' mobile phones. As a preliminary step, before answering the questionnaire, research participants were asked to report on their current mobile phone brand, and whether or not they had any online brand community experience. Among the 240 research participants, the researcher excluded participants who lacked online brand community experience or had invalid data to qualify for data collection. After the researcher excluded participants who did not qualify for data collection, only 203 qualified questionnaire surveys advanced to 
the data collection and analysis phase, which was the questionnaire recovery rate of $84.58 \%$. Papers with less than 200 research participants may be rejected by some editors (Barrett, 2007), and one should endeavor to achieve a sample size above 100, preferably above 200 (Bagozzi \& Yi, 2012). This study sample size just met the requirements suggested by previous researchers. Since it is online survey, WJX automatically stores survey data in excel or SPSS format. Demographic characteristics and mobile phone brands distribution are shown in Table 1. Research participants mostly used several mainstream brands, such as Huawei, Xiaomi, Apple, and Samsung.

\section{Control variables}

Factors such as gender, age, and educational level of online brand community members may have influenced behavior described in previous research (Huang et al., 2015; S. Nambisan \& Baron, 2009); this study takes gender, age, and education as control variables. In addition, in order to eliminate the influence of the region, the participation includes residents of various regions of China as much as possible. Finally, participants came from 24 provinces in China, as shown in Figure 2.

Table 1 Demographic characteristics and brand distribution

\begin{tabular}{|c|c|c|c|c|c|c|c|}
\hline & & $\mathrm{N}$ & $\%$ & & & $\mathrm{~N}$ & \\
\hline & ZTE & 4 & 2.0 & C 1 & $\mathrm{M}$ & 93 & 45.8 \\
\hline & HTC & 2 & 1.0 & & $\bar{F}$ & 110 & 54.2 \\
\hline & Lenovo & 6 & 3.0 & & $18-24$ & 26 & 12.8 \\
\hline & SONY & 2 & 1.0 & & $25-34$ & 67 & 33.0 \\
\hline & Huawei & 61 & 30.0 & Age & $35-44$ & 93 & 45.8 \\
\hline & $\overline{\mathrm{MI}}$ & 45 & 22.2 & & $45-55$ & 15 & 7.4 \\
\hline Brand & Apple & 40 & 19.7 & & $55-$ & 2 & 1.0 \\
\hline & Meizu & 6 & 3.0 & & $\begin{array}{l}\text { High school or } \\
\text { below }\end{array}$ & 5 & 2.5 \\
\hline & Samsung & & 11.3 & Fduc & Junior college & 16 & 7.9 \\
\hline & $\overline{\mathrm{OPPO}}$ & 10 & 4.9 & tion & Undergraduate & 165 & 81.3 \\
\hline & $\overline{\mathrm{VIVO}}$ & 3 & 1.5 & & $\overline{\text { Graduate }}$ & 17 & 8.4 \\
\hline & Other & 1 & 1.0 & & & & \\
\hline
\end{tabular}




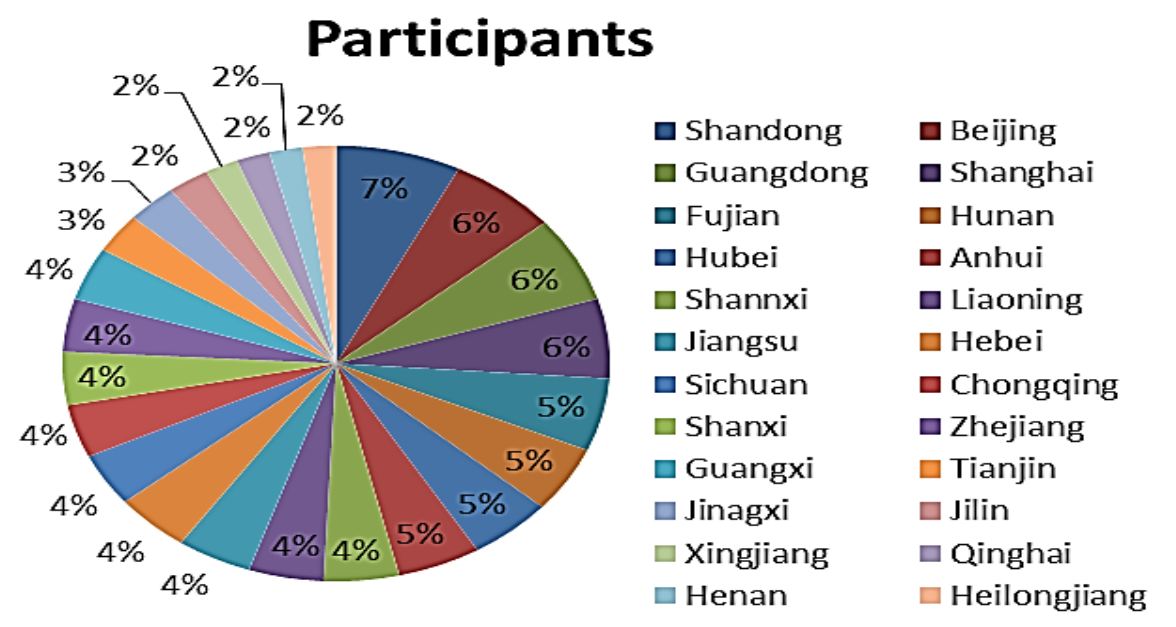

Figure 2 Regional distribution of participants

\section{MEASURES}

Variable measurement. This study deals primarily with five constructs: social value, cognitive value, brand symbolism, customer community engagement, and brand recommendation. The questionnaire items used to measure each construct come mainly from scales commonly used by other researchers. In this research, each scale has three items. They are taken from the following sources: social value, Dholakia et al. (2009); cognitive value, S. Nambisan and Baron (2009); brand symbolism, Homburg et al. (2015); customer community engagement, Vivek (2009); and brand recommendation intention, Maxham and Netemeyer (2002). The measures all consist of a 5-point Likert scale. A value of 1 indicates disagree, 3 indicates hard to say, and 5 indicates agree. For all measurement items and survey details, see Appendix.

\section{MEASUREMENT MODEL}

\section{RELIABILITY}

Reliability analysis generally has two aspects: internal consistency and composite reliability (CR). The internal consistency of each construct was analyzed using confirmatory factor analysis (as shown in Table 2). Cronbach $\alpha$ values of all constructs were above 0.70 , indicating good internal consistency of constructs. In addition, the $\mathrm{CR}$ value of the combined reliability index of all constructs was greater than 0.829 , indicating that the reliability of the combined constructs was relatively high.

Table 2 Constructs and items

\begin{tabular}{lll}
\hline Construct & Item & SFL \\
\hline Social Value & $\begin{array}{l}\text { In the xx brand community, I get to know other } \\
\text { people who are interested in xx brand. }\end{array}$ & 0.840 \\
\cline { 2 - 3 } $\begin{array}{l}\text { Cronbach } \\
\mathrm{CR}=0.735\end{array}$ & $\begin{array}{l}\text { The social aspects of the xx brand community are } \\
\text { important to me. }\end{array}$ & 0.803 \\
\cline { 2 - 3 } $\mathrm{AVE}=0.654$ & $\begin{array}{l}\text { I enjoy communicating with other xx brand com- } \\
\text { munity members. }\end{array}$ & 0.782 \\
\hline
\end{tabular}




\begin{tabular}{|c|c|c|}
\hline Construct & Item & SFL \\
\hline Cognitive Value & $\begin{array}{l}\text { Enhance my knowledge about the product and its } \\
\text { usage by xx brand community. }\end{array}$ & 0.798 \\
\hline$\alpha=0.600$ & $\begin{array}{l}\text { Obtain solutions to specific product-usage related } \\
\text { problems by xx brand communitv. }\end{array}$ & 0.717 \\
\hline $\mathrm{AVE}=0.555$ & $\begin{array}{l}\text { Enhance my knowledge about advances in prod- } \\
\text { uct, related products, and technology by xx brand } \\
\text { community. }\end{array}$ & 0.716 \\
\hline $\begin{array}{l}\text { Brand Symbol- } \\
\text { ism }\end{array}$ & $\begin{array}{l}\text { xx brand would help me in establishing a distinc- } \\
\text { tive image. }\end{array}$ & 0.836 \\
\hline $\begin{array}{l}\text { Cronbach } \\
\alpha=0.770\end{array}$ & $\begin{array}{l}\text { xx brand would be helpful to distinguish myself } \\
\text { from the mass. }\end{array}$ & 0.836 \\
\hline $\begin{array}{l}\mathrm{CR}=0.866 \\
\mathrm{AVE}=0.683\end{array}$ & $\begin{array}{l}\text { xx brand would accurately symbolize or express } \\
\text { my achievement. }\end{array}$ & 0.807 \\
\hline Customer & I like to know more about xx brand community. & 0.825 \\
\hline Engagement & $\begin{array}{l}\text { I love to discuss with my friends at } \mathrm{xx} \text { brand } \\
\text { community. }\end{array}$ & 0.783 \\
\hline $\begin{array}{l}\alpha=0.735 \\
\mathrm{CR}=0.850 \\
\mathrm{AVE}=0.654\end{array}$ & $\begin{array}{l}\text { I enjoy being at xx brand community more when I } \\
\text { am interacting with others. }\end{array}$ & 0.817 \\
\hline Brand Recom- & I would recommend xx brand to my friends. & 0.802 \\
\hline Cronbach & $\begin{array}{l}\text { I would spread positive word-of-mouth about xx } \\
\text { brand. }\end{array}$ & 0.787 \\
\hline $\begin{array}{l}\mathrm{CR}=0.833 \\
\mathrm{AVE}=0.625\end{array}$ & $\begin{array}{l}\text { If my friends were looking for mobile phone, then } \\
\text { I would tell them to try xx brand. }\end{array}$ & 0.782 \\
\hline
\end{tabular}

Note : SFL, Standardized factor loading

\section{VALIDITY}

Different types of validity can be assessed including convergent validity (convergent validity tests that constructs are expected to be related, in fact, are related) and discriminant validity (discriminant validity tests that constructs should have no relationship, in fact, do not have any relationship.). Regarding convergent validity (SFL is used to test the convergence validity), as shown in Table 2 , the factor loading of all the items was greater than 0.716 , and the various fitting indices of the model were $\chi^{2}=102.284, \mathrm{df}=85,\left(\chi^{2} / \mathrm{df}\right)=1.203, \mathrm{p}<0.098, \mathrm{RMSEA}=0.032, \mathrm{CFI}=0.984, \mathrm{NFI}=0.912, \mathrm{IFI}=0.984$, $\mathrm{GFI}=0.938$. The indicators are in line with the standards proposed by scholars, indicating that the model has high convergence validity. In addition, a discriminant validity test was performed by comparing the square of the correlation coefficient between the average variance extraction value (AVE) and the variables. As shown in Table 3, the average variance extraction value AVE of the five variables were all greater than 0.5 . The AVE value of any latent variable was also greater than the square of the correlation coefficient between it and other variables, indicating that the discriminant validity between variables was relatively high. As noted above, CR (Construct Reliability) refers to the relia- 
bility of a combined variable. ACR value greater than 0.6 for a variable indicates that the intrinsic quality of a model is good. The CR values of each latent variable in this paper are greater than or equal to 0.789 , indicating that the model reliability is good. (When the value is higher than 0.70 , it indicates that the variable has better construct reliability.)

Table 3 Correlation matrix

\begin{tabular}{|c|c|c|c|c|c|c|c|}
\hline Variable & 2 & 4 & 5 & mean & STD & AVE & $\mathrm{CR}$ \\
\hline 1. Cognitive Value & 0.745 & & & 4.076 & 0.566 & 0.555 & 0.789 \\
\hline 2. Social Value & $0.512^{* * *} 0.809$ & & & 3.92 & 0.629 & 0.654 & 0.850 \\
\hline $\begin{array}{l}\text { 3. Customer Community } \\
\text { Engagement }\end{array}$ & $0.591^{* * *} 0.706^{* * *} 0.809$ & & & 4.028 & 0.663 & 0.654 & 0.850 \\
\hline 4. Brand Symbolism & $0.336^{* * *} 0.550^{* * *} .543^{* * *}$ & 0.826 & & 3.706 & 0.763 & 0.683 & 0.866 \\
\hline $\begin{array}{l}\text { 5. Brand Recommend Inten- } \\
\text { tion }\end{array}$ & $0.554^{* * *} 0.457^{* * *} 0.502^{* * *}$ & $0.454^{* * *}$ & 0.791 & 4.177 & 0.568 & 0.625 & 0.833 \\
\hline
\end{tabular}

Note: ${ }^{* * *} \mathrm{p}<0.01$

\section{COMMON METHOD VARIANCE}

This paper used two methods to test for a possible homogeneity bias problem. First, the Harman single factor test assumes that if there is methodological variation then the first un-rotated factor accounts for most of the variance when exploratory factor analysis is performed on all items containing all constructs. $(>50 \%)$. In this paper, after the Harman single factor test was conducted, the first unrotated factor variance interpretation rate was $40.40 \%$, indicating that there are no any common method bias problems in this study data. Second, it is generally believed that if correlation coefficients of constructs are greater than 0.9, any common method bias is more serious. As shown in Table 3 , the largest correlation coefficient is 0.709 . The two methods suggest the lack of a serious common method bias problem in this research paper.

\section{RESULTS}

\section{HYPOTHESIS TESTING}

Table 4 shows results of model testing of the study's hypotheses. Model 1 is the impact of the control variables on customer community engagement. Model 2 is the influence of the independent variable (cognitive value and social value) on customer community engagement. According to the data in Table 4, cognitive value $(\beta=0.199, \mathrm{p}<0.01)$ and social value $(\beta=0.361, \mathrm{p}<0.01)$ had a positive effect on customer community engagement; thus, $\mathrm{H} 1$ and $\mathrm{H} 2$ are supported. Customer community engagement $(\beta=0.137, \mathrm{p}<0.01)$ had a positive effect on brand recommendation; thus, H4 was supported. 
Table 4 Model test result

\begin{tabular}{|c|c|c|c|c|c|c|c|}
\hline & \multicolumn{4}{|c|}{ DV : Customer Community Engagement } & \multicolumn{3}{|c|}{$\begin{array}{c}\text { DV : Brand Recommend } \\
\text { Intention }\end{array}$} \\
\hline & Model 1 & Model2 & Model3 & Model4 & Model5 & Model6 & Model7 \\
\hline \multicolumn{8}{|l|}{ Control Variable } \\
\hline Gender & 0.049 & 0.049 & 0.055 & 0.042 & -0.080 & -0.019 & -0.029 \\
\hline Age & $0.173 * * *$ & $0.083 * *$ & $0.082 * *$ & 0.055 & $0.095 * *$ & 0.00900 & -0.008 \\
\hline Education & 0.103 & -0.043 & -0.058 & -0.053 & 0.078 & -0.0260 & -0.017 \\
\hline \multicolumn{8}{|l|}{ Main effect } \\
\hline Cognitive Value & & $0.199 * * *$ & $0.190 * * *$ & $0.233 * * *$ & & $0.271 * * *$ & $0.230 * * *$ \\
\hline Social Value & & $0.361 * * *$ & $0.292 * * *$ & $0.200 * * *$ & & $0.126 * * *$ & 0.051 \\
\hline Brand Symbolism & & & $0.135 * * *$ & $0.128 * * *$ & & & \\
\hline \multicolumn{8}{|l|}{ Interaction effect } \\
\hline \multicolumn{4}{|c|}{ Cognitive Valuex Brand Symbolism } & 0.024 & & & \\
\hline \multicolumn{4}{|c|}{ Social Value $\times$ Brand Symbolism } & $-0.102 * * *$ & & & \\
\hline R Square & 0.054 & 0.584 & 0.612 & 0.645 & 0.031 & 0.438 & 0.466 \\
\hline Adjusted R Square & 0.040 & 0.573 & 0.600 & 0.630 & 0.016 & 0.424 & 0.450 \\
\hline $\mathrm{F}$ & 3.777 & 55.22 & 51.55 & 44.04 & 2.097 & 30.75 & 28.49 \\
\hline $\mathrm{N}$ & 203 & 203 & 203 & 203 & 203 & 203 & 203 \\
\hline
\end{tabular}

Note : *The coefficient is the normalized value; ${ }^{* *}$ statistically significant with $\mathrm{p}=<0.05$;

$* * *$ statistically significant with $\mathrm{p}=<0.01$

\section{MEDIATION EFFECT}

This study also examines the mediating effects of customer community engagement as found in previous studies using the method promoted by R. Baron and Kenny (1986). First, the independent variable and the dependent variable are regressed, and the regression coefficient is the premise of the intermediary test. Second, when the regression coefficient is significant in the first step, the independent variables are regressed to the intermediary variables. A significant regression coefficient indicates that the independent variables have influence on the intermediary variables. Finally, the independent variable and the mediating variable are returned to the dependent variable at the same time. A mediating effect appears to exist if (a) the mediator variable is significant for the dependent variable, and (b) the regression coefficient of the independent variable is not significant for the dependent variable, and (c) the factor is significantly smaller than the coefficient for the dependent variable to directly return to the dependent variable. The results of the mediation tests in this paper are shown in Models 2, 6, and 7 in Table 4. Model 6 shows that the regression coefficients of cognitive value, social value, and brand recommendation were significant, and there is a basis for further mediation testing. Model 7 shows that after joining customer community engagement, the regression coefficient of cognitive value to brand recommendation remained significant, but its regression coefficient value was reduced by 0.041 . The Sobel test resulted in a Sobel Test value of $4.851(p<0.00)$. The results show that customer community engagement played a part in the intermediary role. Therefore, H5a is verified. Finally, after joining customer community engagement, the regression coefficient of the social value to the brand recommendation was not significant, indicating that customer community engagement played a full intermediary role. H5b is also verified. 


\section{MODERATING EFFECT}

Before conducting the moderating effect test, this paper first centralized the independent variable (cognitive value and social value) and the proposed moderating variable (brand symbolism) to reducing any problem of multicollinearity. Regression results showed that brand symbolism $(\beta=0.135, \mathrm{p}$ $<0.01)$ added in Model 3 itself had a positive impact on the customer community engagement. Model 4 involves an interaction item; brand symbolism had no significant effect on the relationship between cognitive value and customer community engagement, and cognitive value $\times$ brand symbol $(\beta=0.024$, $\mathrm{p}>0.1)$. H3a was not supported. Brand symbolism appeared to negatively regulate the relationship between social value and customer community engagement, and social value $\times$ brand symbolism $(\beta=-$ 0.102, $\mathrm{p}<0.01)$. H3b was supported.

\section{FINDINGS AND DISCUSSION}

Customer community engagement goes beyond purchasing (Doorn et al., 2010) and is an interactive experience for customers (Brodie et al., 2013). Businesses establish online brand community via the Internet and social media to facilitate interaction between customers and brands, and customers and customers; it also promotes an emotional relationship between customers and brands. The interactive nature of the online brand community stimulates behaviors that are beneficial to businesses and other customers beyond the purchase behavior, such as word-of-mouth communication, reviews, helping others, product improvement suggestions, and new product development ideas. This study explored the factors that affect customer community engagement as well as the circumstances under which these factors are conducive to or inhibit customer's community engagement.

First, influenced by previous research studies; this study divided customers' interaction objectives in the online brand community into product-based activities and community-based (social) interactions (Chang et al., 2015; Dholakia et al., 2009; S. Nambisan \& Baron, 2009; Wang \& Ma, 2013). For the customer, the two forms of interaction produce different interactive value needs. Product-based activities are based on the customer's cognitive needs, and community (social) interactions are based on the customer's social needs. Customers' participation reflects these two needs (S. Nambisan \& Baron, 2009). According to this study's empirical analysis, customer demands for cognitive value and social value have a positive effect on customer community engagement. The higher the level of connection between customers and online brand community, the greater the interaction of the customer in the online brand community and the more the user-generated word-of-mouth communication information. Regarding their cognitive value needs, customers obtain knowledge about the product from the online brand community and become more efficient in using or processing the product. Based on the principle of reciprocity and in order to use their expertise to enhance their position in the online brand community, customers are more likely to respond to other people's problems, propose product improvements, and provide development opinions and suggestions. In addition, as interaction in the online brand community develops and deepens, customers gradually gain the recognition of others, establish close friendships, and expand their social networks. In order to maintain the relationships or responsibilities among friends, customers may also engage in behaviors such as mutual assistance, cooperation, and word-of-mouth communication. The results of further mediation tests suggest that customer community engagement plays a partial intermediary role in the relationship between community perceived value and brand recommendation, and it plays a role in the mediation of community social value and brand recommendation.

Second, this study introduces brand symbol factors to analyze under what circumstances customers' two community value needs will be affected by the customer community relationship. According to the results, brand symbolism has no significant moderating effect on the relationship between cognitive value and customer community engagement, but it has a negative effect on the relationship between social value and customer community engagement. For a product with a relatively high technological content such as a mobile phone, no matter how symbolic the brand, little difference occurs between brands in the consumer's pursuit of cognitive value such as product features and usage 
methods. Therefore, this study's researcher concludes that the symbolic level of the brand does not have a significant difference in the moderating effect of the relationship between cognitive value and customer community engagement. However, if a brand with high symbolic value represents higher social status and prestige value, customers may use this brand symbolism to confirm their uniqueness and superiority and those of other users. If, however, customers perceive that more people using the brand or the brand experience, they may feel that their similarity with others is high or that the brand has become a popular brand. Therefore, many customer interactions in the online brand community may reduce the customer's perception of brand prestige value and uniqueness. At this point, the value appeal of customers participating in the online brand community may become more about the cognitive value of product knowledge rather than the seeking of social value. Therefore, online brand community and brand symbolism that embody social value is increased, and the relationship between customer community behavior/attitude is inhibited rather than matched.

\section{CONCLUSION}

\section{MARKETING SIGNIFICANCE}

This study has practical significance for businesses. First, in practice, the value of consumers is not only limited to purchases, but also reflected in the value of recommendations and sharing. Companies may utilize engagement indicators to measure the customers' future value. Second, before developing an online brand community, companies might clarify the customers' perception of the brand image; for example, whether it is high symbolic or low symbolic; or whether the functional value is important. Third, companies can manage and control the types and interactive styles of community information by clarifying the characteristics of information generation and transmission and specific website functions. Enterprises can decide the type of value provided by the online brand community to match their own brand symbolism, thereby making the online brand community more successful. In other words, companies can manipulate the information type (social or cognitive) in the online brand community and establish relevant rules of behavior to confirm whether it is beneficial to cognitive needs or social needs for customers. A specific website (community) function could facilitate the company's managing the community without too much involvement in the customer interaction, so as to avoid interfering with customers' free interaction in the online brand community. For example, for high symbolic brands, the online brand community should use information that is formally related to the use of products or brands, maintenance and upgrading, and innovation to solve problems, and reduce social entertainment. In addition, the online brand community design is based principally on simple style which can satisfy the display and reception of information as well as replies. Relatively speaking, for a symbolically low brand, the information features do not need to be overrestricted, and the design of the online brand community should include rich functions to satisfy customers' social interaction needs.

In general, brands with high social value are not suitable for creating communities that emphasize social interaction, which in turn reduces the symbolic value of the brand. Interaction between peers may reduce the symbolic value of the pursuit of social distance. Therefore, the most appropriate online brand community for a brand with high social symbolic values is vertical display (such as Weibo show off).

\section{LIMITATIONS AND FUTURE RESEARCH PROSPECTS}

This study used mobile phone users and cross-sectional data. Future research should expand the populations studied and further explore the impact of customer community values and brand recommendation intentions from a dynamic perspective. In addition, this study investigated the cognitive and social values of an online brand community as a whole. According to S. Nambisan and Baron (2009), however, personal values and entertainment values also appeal to customers in online 
brand communities. Future, studies may further subdivide customer community value needs to address additional impacts on the customer community.

\section{ACKNOWLEDGMENTS}

This research study was supported with grant from the Key Research Institute of Philosophies and Social Sciences in Guangxi Universities (Grant No.17YB001), the Natural Science Foundation of Guangxi Zhuang Autonomous Region (Grant No.AD19245142) and Scientific Research Foundation for the PhD (Guilin University of Technology, Grant No.GLUTQD2018054).

\section{REFERENCES}

Aaker, D. A. (1996). Building strong brands. Free Press.

Aaker, J. L. (1997). Dimensions of brand personality. Journal of Marketing Research, 34(3), 347. https://doi.org/10.2307/3151897

Aaker, J. L. (1999). The malleable self: The role of self-expression in persuasion. Journal of Marketing Research, 36(1), 45. https://doi.org/10.2307/3151914

Algesheimer, R., \& Dholakia, P. M. (2006). Do customer communities pay off? Harvard Business Review, 84(11), 26-30.

Algesheimer, R., Dholakia, U. M., \& Herrmann, A. (2005). The social influence of brand community: Evidence from European car clubs. Journal of Marketing, 69(3), 19-34. https://doi.org/10.1509/jmkg.69.3.19.66363

Anderson, E. W., Fornell, C., \& Mazvancheryl, S. K. (2004). Customer satisfaction and shareholder value. Journal of Marketing, 68(4), 172-185. https://doi.org/10.1509/jmkg.68.4.172.42723

Bagozzi, R. P., \& Dholakia, U. M. (2006). Antecedents and purchase consequences of customer participation in small group brand communities. International Journal of Research in Marketing, 23(1), 45-61. https://doi.org/10.1016/i.ijresmar.2006.01.005

Bagozzi, R. P., \& Yi, Y. (2012). Specification, evaluation, and interpretation of structural equation models. Journal of the Academy of Marketing Science, 40(1), 8-34. https://doi.org/10.1007/s11747-011-0278-x

Baldus, B. J., Voorhees, C., \& Calantone, R. (2015). Online brand community engagement: Scale development and validation. Journal of Business Research, 68(5), 978-985. https://doi.org/10.1016/i.jbusres.2014.09.035

Baron, R. M., \& Kenny, D. A. (1986). The moderator-mediator variable distinction in social psychological research: Conceptual, strategic, and statistical considerations. Journal of Personality and Social Psychology, 51(6), 1173-1182. https://doi.org/10.1037/0022-3514.51.6.1173

Baron, S., \& Warnaby, G. (2011). Individual customers' use and integration of resources: Empirical findings and organizational implications in the context of value co-creation. Industrial Marketing Management, 40(2), 211-218. https://doi.org/10.1016/j.indmarman.2010.06.033

Barrett, P. (2007). Structural equation modeling: Adjudging model fit. Personality and Individual Differences, 42(5), 815-824. https://doi.org/10.1016/j.paid.2006.09.018

Bauer, H. H., \& Hammerschmidt, M. (2005). Customer-based corporate valuation. Management Decision, 43(3), 331-348. https://doi.org/10.1108/00251740510589733

Brodie, R. J., Hollebeek, L. D., Jurić, B., \& Ilić, A. (2011). Customer engagement. Journal of Service Research, 14(3), 252-271. https://doi.org/10.1177/1094670511411703

Brodie, R. J., Ilic, A., Juric, B., \& Hollebeek, L. (2013). Consumer engagement in a virtual brand community: An exploratory analysis. Journal of Business Research, 66(1), 105-114.

https://doi.org/10.1016/i.jbusres.2011.07.029 
Burnham, T. A., Frels, J. K., \& Mahajan, V. (2003). Consumer switching costs: A typology, antecedents, and consequences. Journal of the Academy of Marketing Science, 31(2), 109-126. https://doi.org/10.1177/0092070302250897

Casaló, L. V., Flavián, C., \& Guinalíu, M. (2008). Promoting consumer's participation in virtual brand communities: A new paradigm in branding strategy. Journal of Marketing Communications, 14(1), 19-36. https://doi.org/10.1080/13527260701535236

Chang, Y., Lu, Z., \& Zhu, D. (2015). The influence of online social support on customer citizenship behaviors: An empirical study of online brand communities. Chinese Journal of Management, 12(10), 1536-1543. https://doi.org/10.3969/j.issn.1672-884x.2015.10.017

Chebat, J.-C., \& Kollias, P. (2000). The impact of empowerment on customer contact employees' roles in service organizations. Journal of Service Research, 3(1), 66-81. https://doi.org/10.1177/109467050031005

Dholakia, U. M., Bagozzi, R. P., Klein, L., \& Pearo, L. K. (2004). A social influence model of consumer participation in network- and small-group-based virtual communities. International Journal of Research in Marketing, 21(3), 241-263. https://doi.org/10.1016/j.ijresmar.2003.12.004

Dholakia, U. M., Blazevic, V., Wiertz, C., \& Algesheimer, R. (2009). Communal service delivery: How customers benefit from participation in firm-hosted virtual P3 communities. Journal of Service Research, 12(2), 208226. https://doi.org/10.1177/1094670509338618

Ernst, H., Hoyer, W., Krafft, M., \& Soll, J.-H. (2017). Virtual co-creation with customers in the early stages of new product development. Ssm, 49(251), 1-45. https://doi.org/10.2139/ssrn.3053800

Fuller, J., Bartl, M., Ernst, H., \& Muhlbacher, H. (2004). Community based innovation: A method to utilize the innovative potential of online communities. In Proceedings of the 37th Annual Hawaii International Conference on System Sciences, 2004. IEEE. https://ieeexplore.ieee.org/abstract/document/1265464

Füller, J., Faullant, R., \& Matzler, K. (2010). Triggers for virtual customer integration in the development of medical equipment - From a manufacturer and a user's perspective. Industrial Marketing Management, 39(8), 1376-1383. https://doi.org/10.1016/j.indmarman.2010.04.003

Godes, D., \& Mayzlin, D. (2009). Firm-created word-of-mouth communication: Evidence from a field test. Marketing Science, 28(4), 721-739. https://doi.org/10.1287/mksc.1080.0444

Gopalakrishna, S., Malthouse, E. C., \& Lawrence, J. M. (2019). Managing customer engagement at trade shows. Industrial Marketing Management, 81(December), 99-114. https://doi.org/10.1016/j.indmarman.2017.11.015

Gray, P. H., \& Meister, D. B. (2004). Knowledge sourcing effectiveness. Management Science, 50(6), 821-834. https://doi.org/10.1287/mnsc.1030.0192

Gruca, T. S., \& Rego, L. L. (2005). Customer satisfaction, cash flow, and shareholder value. Journal of Marketing, 69(3), 115-130. https://doi.org/10.1509/jmkg.69.3.115.66364

Gvili, Y., \& Levy, S. (2018). Consumer engagement with eWOM on social media: The role of social capital. Online Information Review, 42(4), 482-505. https://doi.org/10.1108/OIR-05-2017-0158

Hanson, S., Jiang, L., \& Dahl, D. (2019). Enhancing consumer engagement in an online brand community via user reputation signals: A multi-method analysis. Journal of the Academy of Marketing Science, 47(2), 349-367. https://doi.org/10.1007/s11747-018-0617-2

Harhoff, D., Henkel, J., \& von Hippel, E. (2003). Profiting from voluntary information spillovers: How users benefit by freely revealing their innovations. Research Policy, 32(10), 1753-1769. https://doi.org/10.1016/S0048-7333(03)00061-1

Hennig-Thurau, T., Gwinner, K. P., Walsh, G., \& Gremler, D. D. (2004). Electronic word-of-mouth via consumer-opinion platforms: What motivates consumers to articulate themselves on the Internet? Journal of Interactive Marketing, 18(1), 38-52. https://doi.org/10.1002/dir.10073

Hollebeek, L. D., Glynn, M. S., \& Brodie, R. J. (2014). Consumer brand engagement in social media: Conceptualization, scale development and validation. Journal of Interactive Marketing, 28(2), 149-165.

https://doi.org/10.1016/j.intmar.2013.12.002 
Homburg, C., Ehm, L., \& Artz, M. (2015). Measuring and managing consumer sentiment in an online community environment. Journal of Marketing Research, 52(5), 629-641. https://doi.org/10.1509/jmr.11.0448

Homburg, C., Schwemmle, M., \& Kuehnl, C. (2015). New product design: Concept, measurement, and consequences. Journal of Marketing, 79(3), 41-56. https://doi.org/10.1509/jm.14.0199

Hoyer, W. D., Chandy, R., Dorotic, M., Krafft, M., \& Singh, S. S. (2010). Consumer cocreation in new product development. Journal of Service Research, 13(3), 283-296. https://doi.org/10.1177/1094670510375604

Hsu, C. P., Chiang, Y. F., \& Huang, H. C. (2012). How experience-driven community identification generates trust and engagement. Online Information Review, 36(1), 72-88. https://doi.org/10.1108/14684521211206971

Huang, M., Liao, J., \& Zhou, N. (2015). Can community experience lead to brand loyalty? A study of the effect and mechanism of different experience dimensions. Nankai Business Review, 18(3), 151-160.

Jaakkola, E., \& Alexander, M. (2014). The role of customer engagement behavior in value co-creation. Journal of Service Research, 17(3), 247-261. https://doi.org/10.1177/1094670514529187

Jang, H., Olfman, L., Ko, I., Koh, J., \& Kim, K. (2008). The influence of on-line brand community characteristics on community commitment and brand loyalty. International Journal of Electronic Commerce, 12(3), 57-80. https://doi.org/10.2753/JEC1086-4415120304

Jeppesen, L. B., \& Molin, M. J. (2003). Consumers as co-developers: Learning and innovation outside the firm. Technology Analysis \& Strategic Management, 15(3), 363-383. https://doi.org/10.1080/09537320310001601531

Johnson, D. S., \& Lowe, B. (2015). Emotional support, perceived corporate ownership and skepticism toward out-groups in virtual communities. Journal of Interactive Marketing, 29, 1-10. https://doi.org/10.1016/j.intmar.2014.07.002

Kang, M., \& Shin, D. H. (2016). The effect of customers' perceived benefits on virtual brand community loyalty. Online Information Review, 40(3), 298-315. https://doi.org/10.1108/OIR-09-2015-0300

Keller, K. L. (1993). Conceptualizing, measuring, managing customer-based brand equity. Journal of Marketing, 57(1), 1-21. https://doi.org/10.1177/002224299305700101

Khan, I., Hollebeek, L. D., Fatma, M., Ul Islam, J., \& Rahman, Z. (2019). Brand engagement and experience in online services. Journal of Services Marketing, (October). https://doi.org/10.1108/JSM-03-2019-0106

Kozinets, R. V, de Valck, K., Wojnicki, A. C., \& Wilner, S. J. (2010). Networked narratives: Understanding word-of-mouth marketing in online communities. Journal of Marketing, 74(2), 71-89. https://doi.org/10.1509/jmkg.74.2.71

Kumar, V., Aksoy, L., Donkers, B., Venkatesan, R., Wiesel, T., \& Tillmanns, S. (2010). Undervalued or overvalued customers: Capturing total customer engagement value. Journal of Service Research, 13(3), 297-310. https://doi.org/10.1177/1094670510375602

Kumar, V., \& Pansari, A. (2016). Competitive advantage through engagement. Journal of Marketing Research, 53(4), 497-514. https://doi.org/10.1509/jmr.15.0044

Lautman, M. R. (1991). End-benefit segmentation and prototypical bonding. Journal of Advertising Research, 31(3), 9-18.

Le, T. D. (2018). Influence of WOM and content type on online engagement in consumption communities: The information flow from discussion forums to Facebook. Online Information Review, 42(2), 161-175. https://doi.org/10.1108/OIR-09-2016-0246

Liu, X., Shin, H., \& Burns, A. C. (2019). Examining the impact of luxury brand's social media marketing on customer engagement: Using big data analytics and natural language processing. Journal of Business Research, May, 1-12. https://doi.org/10.1016/i.jbusres.2019.04.042

Loureiro, S. M. C., Gorgus, T., \& Kaufmann, H. R. (2017). Antecedents and outcomes of online brand engagement: The role of brand love on enhancing electronic-word-of-mouth. Online Information Review, 41(7), 985-1005. https://doi.org/10.1108/OIR-08-2016-0236 
Consumer Engagement in Online Brand Communities

Luarn, P., Lin, Y. F., \& Chiu, Y. P. (2015). Influence of Facebook brand-page posts on online engagement. Online Information Review, 39(4), 505-519. https://doi.org/10.1108/OIR-01-2015-0029

Mathwick, C., Wiertz, C., \& de Ruyter, K. (2008). Social capital production in a virtual P3 community. Journal of Consumer Research, 34(6), 832-849. https://doi.org/10.1086/523291

Maxham, J. G., \& Netemeyer, R. G. (2002). A longitudinal study of complaining customers' evaluations of multiple service failures and recovery efforts. Journal of Marketing, 66(4), 57-71. https://doi.org/10.1509/jmkg.66.4.57.18512

McAlexander, J. H., Schouten, J. W., \& Koenig, H. F. (2002). Building brand community. Journal of Marketing, 66(1), 38-54. https://doi.org/10.1509/jmkg.66.1.38.18451

McEwen, W. J. (2001). The engagement imperative-How bonded are US customers to the brands they use. Gallup Management Journal.

McEwen, W. J., \& Fleming, J. H. (2003). Customer satisfaction doesn't count. Gallup Management Journal, 13, 14.

McLure, Wasko, M., \& Faraj, S. (2000). "It is what one does": Why people participate and help others in electronic communities of practice. The Journal of Strategic Information Systems, 9(2-3), 155-173. https://doi.org/10.1016/S0963-8687(00)00045-7

Mollen, A., \& Wilson, H. (2010). Engagement, telepresence and interactivity in online consumer experience: Reconciling scholastic and managerial perspectives. Journal of Business Research, 63(9-10), 919-925. https://doi.org/10.1016/j.jbusres.2009.05.014

Muniz, A. M., \& O’Guinn, T. C. (2001). Brand community. Journal of Consumer Research, 27(4), 412-432. https://doi.org/10.1086/319618

Nambisan, P., \& Watt, J. H. (2011). Managing customer experiences in online product communities. Journal of Business Research, 64(8), 889-895. https://doi.org/10.1016/j.jbusres.2010.09.006

Nambisan, S. (2002). Designing virtual customer environments for new product development: Toward a theory. Academy of Management Review, 27(3), 392-413. https://doi.org/10.5465/amr.2002.7389914

Nambisan, S., \& Baron, R. A. (2007). Interactions in virtual customer environments: Implications for product support and customer relationship management. Journal of Interactive Marketing, 21(2), 42-62. https://doi.org/10.1002/dir.20077

Nambisan, S., \& Baron, R. A. (2009). Virtual customer environments: Testing a model of voluntary participation in value co-creation activities. Journal of Product Innovation Management, 26(4), 388-406. https://doi.org/10.1111/j.1540-5885.2009.00667.x

Nambisan, S, \& Nambisan, P. (2008). How to profit from a better virtual customer environment. MIT Sloan Management Review, 49(3), 53.

Nolan, T., Brizland, R., \& Macaulay, L. (2007). Individual trust and development of online business communities. Information Technology \& People, 20(1), 53-71. https://doi.org/10.1108/09593840710730554

Obilo, O. O., Chefor, E., \& Saleh, A. (2020). Revisiting the consumer brand engagement concept. Journal of Business Research, (January). https://doi.org/10.1016/j.jbusres.2019.12.023

Orth, U. R., \& De Marchi, R. (2007). Understanding the relationships between functional, symbolic, and experiential brand beliefs, product experiential attributes, and product schema: Advertising-trial interactions revisited. The Journal of Marketing Theory and Practice, 15(3), 219-233. https://doi.org/10.2753/MTP1069$\underline{6679150303}$

Rather, R. A. (2019). Consequences of consumer engagement in service marketing: An empirical exploration. Journal of Global Marketing, 32(2), 116-135. https://doi.org/10.1080/08911762.2018.1454995

Ray, S., Kim, S. S., \& Morris, J. G. (2014). The central role of engagement in online communities. Information Systems Research, 25(3), 528-546. https://doi.org/10.1287/isre.2014.0525

Rego, L. L., Billett, M. T., \& Morgan, N. A. (2009). Consumer-based brand equity and firm risk. Journal of Marketing, 73(6), 47-60. https://doi.org/10.1509/jmkg.73.6.47 
Rosenbaum, M. S., \& Massiah, C. A. (2007). When customers receive support from other customers: Exploring the influence of intercustomer social support on customer voluntary performance. Journal of Service Research, 9(3), 257-270. https://doi.org/10.1177/1094670506295851

Rothaermel, F. (2001). Virtual internet communities and commercial success: Individual and community-level theory grounded in the atypical case of TimeZone.com. Journal of Management, 27(3), 297-312. https://doi.org/10.1016/S0149-2063(01)00093-9

Tian, K. T., Bearden, W. O., \& Hunter, G. L. (2001). Consumers' need for uniqueness: Scale development and validation. Journal of Consumer Research, 28(1), 50-66. https://doi.org/10.1086/321947

van Doorn, J., Lemon, K. N., Mittal, V., Nass, S., Pick, D., Pirner, P., \& Verhoef, P. C. (2010). Customer engagement behavior: Theoretical foundations and research directions. Journal of Service Research, 13(3), 253 266. https://doi.org/10.1177/1094670510375599

Verhoef, P. C., Reinartz, W. J., \& Krafft, M. (2010). Customer engagement as a new perspective in customer management. Journal of Service Research, 13(3), 247-252. https://doi.org/10.1177/1094670510375461

Verona, G. (2003). Unbundling dynamic capabilities: An exploratory study of continuous product innovation. Industrial and Corporate Change, 12(3), 577-606. https://doi.org/10.1093/icc/12.3.577

Vigneron, F., \& Johnson, L. W. (2004). Measuring perceptions of brand luxury. Journal of Brand Management, 11(6), 484-506. https://doi.org/10.1057/palgrave.bm.2540194

Vivek, S. D. (2009). A scale of consumer engagement (Doctoral dissertation). The University of Alabama.

Vohra, A., \& Bhardwaj, N. (2019). Customer engagement in an e-commerce brand community: An empirical comparison of alternate models. Journal of Research in Interactive Marketing, 13(1), 2-25. https://doi.org/10.1108/JRIM-01-2018-0003

Wang, Y., \& Ma, S. (2013). The key drivers of customer interactions and their effects on customer satisfaction: An empirical study in the context of virtual brand community. Chinese Journal of Management, 10(9), 13751383.

Wasko, M. M., \& Faraj, S. (2005). Why should I share? Examining social capital and knowledge contribution in electronic networks of practice. MIS Quarterly, 29(1), 35-57. https://doi.org/10.2307/25148667

Wiertz, C., \& de Ruyter, K. (2007). Beyond the call of duty: Why customers contribute to firm-hosted commercial online communities. Organization Studies, 28(3), 347-376. https://doi.org/10.1177/0170840607076003

Wirtz, J., den Ambtman, A., Bloemer, J., Horváth, C., Ramaseshan, B., van de Klundert, J., \& Kandampully, J. (2013). Managing brands and customer engagement in online brand communities. Journal of Service Management, 24(3), 223-244. https://doi.org/10.1108/09564231311326978

Yang, M., Ren, Y., \& Adomavicius, G. (2019). Understanding user-generated content and customer engagement on Facebook business pages. Information Systems Research, 30(3), 839-855. https://doi.org/10.1287/isre.2019.0834

Zhou, T. (2011). Understanding online community user participation: A social influence perspective. Internet Research, 21(1), 67-81. https://doi.org/10.1108/10662241111104884 


\section{APPENDIX}

Dear Madam / Sir,

We are conducting a survey of consumer community interactions with mobile phone products online. Please make a corresponding evaluation of XX MOBILE PHONE and its online community based on your experience using XX MOBILE PHONE and your experience in participating in the XX MOBILE PHONE online brand community. The data collected in this survey is only used for academic research and will not be identified separately. Please rest assured to fill it out.

Thank you for your cooperation!

First Part

The mobile phone brand you are using is:

\begin{tabular}{|l|l|}
\hline ZTE & 1 \\
\hline HTC & 2 \\
\hline Lenovo & 3 \\
\hline SONY & 4 \\
\hline Huawei & 5 \\
\hline MI & 6 \\
\hline Apple & 7 \\
\hline Meizu & 8 \\
\hline Samsung & 9 \\
\hline Le & 10 \\
\hline OPPO & 11 \\
\hline VIVO & 12 \\
\hline Honor & 13 \\
\hline Other brand & 14 \\
\hline
\end{tabular}

Do you have any experience in the XX online brand community, such as posting, browsing, and replying to posts.

\begin{tabular}{|l|l|}
\hline Yes, I do & 1 \\
\hline No, I don't & 2 \\
\hline
\end{tabular}




\section{Second Part}

Note: The XX brand mentioned in the following questions refers to the mobile phone brand you are using.

1. Based on your experience in the XX online brand community, to what extent do you agree with the following statement?

\begin{tabular}{|l|l|l|l|l|l|}
\hline \multicolumn{2}{|l|}{ Disagree } & \multicolumn{5}{|c|}{ Agree } \\
\hline $\begin{array}{l}\text { xx brand would help me in establishing a distinctive } \\
\text { image. }\end{array}$ & 1 & 2 & 3 & 4 & 5 \\
\hline $\begin{array}{l}\text { xx brand would be helpful to distinguish myself from } \\
\text { the mass. }\end{array}$ & 1 & 2 & 3 & 4 & 5 \\
\hline $\begin{array}{l}\text { xx brand would accurately symbolize or express my } \\
\text { achievement. }\end{array}$ & 1 & 2 & 3 & 4 & 5 \\
\hline
\end{tabular}

2. Based on your experience in the XX online brand community, to what extent do you agree with the following statement?

\begin{tabular}{|l|l|l|l|l|l|}
\hline & Disagree & \multicolumn{5}{|c|}{ Agree } \\
\hline $\begin{array}{l}\text { In the xx brand community, I get to know other peo- } \\
\text { ple who are interested in xx brand. }\end{array}$ & 1 & 2 & 3 & 4 & 5 \\
\hline $\begin{array}{l}\text { The social aspects of the xx brand community are im- } \\
\text { portant to me. }\end{array}$ & 1 & 2 & 3 & 4 & 5 \\
\hline $\begin{array}{l}\text { I enjoy communicating with other xx brand communi- } \\
\text { ty members. }\end{array}$ & 1 & 2 & 3 & 4 & 5 \\
\hline
\end{tabular}

3. Based on your experience in the XX online brand community, to what extent do you agree with the following statement?

\begin{tabular}{|l|l|l|l|l|l|}
\hline \multicolumn{2}{|l|}{ Disagree } & \multicolumn{5}{|c|}{ Agree } \\
\hline $\begin{array}{l}\text { Enhance my knowledge about the product and its us- } \\
\text { age by xx brand community. }\end{array}$ & 1 & 2 & 3 & 4 & 5 \\
\hline $\begin{array}{l}\text { Obtain solutions to specific product-usage related } \\
\text { problems by xx brand community. }\end{array}$ & 1 & 2 & 3 & 4 & 5 \\
\hline $\begin{array}{l}\text { Enhance my knowledge about advances in product, } \\
\text { related products, and technology by xx brand commu- } \\
\text { nity. }\end{array}$ & 1 & 2 & 3 & 4 & 5 \\
\hline
\end{tabular}

4. Based on your experience in the XX online brand community, to what extent do you agree with the following statement?

\begin{tabular}{|l|l|l|l|l|l|}
\hline & Disagree & \multicolumn{5}{|c|}{ Agree } \\
\hline I like to know more about xx brand community. & 1 & 2 & 3 & 4 & 5 \\
\hline $\begin{array}{l}\text { I love to discuss with my friends at xx brand commu- } \\
\text { nity. }\end{array}$ & 1 & 2 & 3 & 4 & 5 \\
\hline $\begin{array}{l}\text { I enjoy being at xx brand community more when I am } \\
\text { interacting with others. }\end{array}$ & 1 & 2 & 3 & 4 & 5 \\
\hline
\end{tabular}


5. How likely are you to recommend someone to use a XX online brand phone in the future?

\begin{tabular}{|l|l|l|l|l|l|}
\hline & Disagree & \multicolumn{5}{|l|}{ Agree } \\
\hline I would recommend xx brand to my friends. & 1 & 2 & 3 & 4 & 5 \\
\hline $\begin{array}{l}\text { I would spread positive word-of-mouth about xx } \\
\text { brand. }\end{array}$ & 1 & 2 & 3 & 4 & 5 \\
\hline $\begin{array}{l}\text { If my friends were looking for mobile phone, then I } \\
\text { would tell them to try xx brand. }\end{array}$ & 1 & 2 & 3 & 4 & 5 \\
\hline
\end{tabular}

Third Part

1. You are a

\begin{tabular}{|l|l|}
\hline Boy & 1 \\
\hline Girl & 2 \\
\hline
\end{tabular}

2. Your age is

\begin{tabular}{|l|l|}
\hline Under 18 years & 1 \\
\hline $18-24$ years & 2 \\
\hline $25-34$ years & 3 \\
\hline $35-44$ years & 4 \\
\hline $45-55$ years & 5 \\
\hline Over 50 years & 6 \\
\hline
\end{tabular}

3. Your education level is

\begin{tabular}{|l|l|}
\hline High school or below & 1 \\
\hline Junior college & 2 \\
\hline Undergraduate & 3 \\
\hline Graduate & 4 \\
\hline
\end{tabular}

\section{BIOGRAPHY}

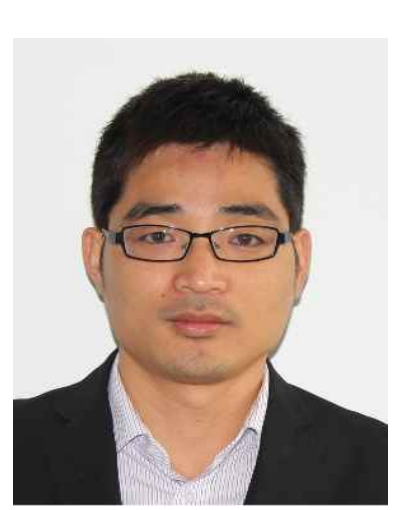

Haili Pan is a Lecturer at the Business School, Guilin University of Technology in Guilin, China. He teaches courses in marketing, brand management, and consumer behavior. He earned his $\mathrm{PhD}$ degree from Wuhan University. His research interests include: online brand community knowledge management; consumer behavior; and value cocreation. 